DOI: https://doi.org/10.24127/ajpm.v10i1.3414

\title{
MULTIMODAL MODEL MELALUI E-LEARNING PADA MATA KULIAH GEOMETRI BIDANG DI MASA PANDEMI COVID 19
}

\author{
Titin Masfingatin $^{1 *}$, Wasilatul Murtafiah ${ }^{2}$, Ika Krisdiana ${ }^{3}$, Reza Kusuma \\ Setyansah $^{4}$, Vera Dewi Susanti ${ }^{5}$ \\ $1^{*, 2,3,4,5}$ Pendidikan Matematika, Universitas PGRI Madiun, Jawa Timur, Indonesia \\ *Corresponding author \\ E-mail: $\quad$ titin.mathedu@unipma.ac.id $^{1 *}$ \\ wasila.mathedu@unipma.ac.id ${ }^{2}$ \\ ikakrisdiana.mathedu@unipma.ac.id ${ }^{3)}$ \\ reza.mathedu@unipma.sc.id ${ }^{4)}$ \\ vera.mathedu@unipma.ac.id ${ }^{5)}$
}

Received 21 December 2020; Received in revised form 08 March 2021; Accepted 01 April 2021

\begin{abstract}
Abstrak
Pada masa pandemi covid 19 pembelajaran dilaksanakan secara online dengan memanfaatkan $e$-learning. Multimodal model merupakan komponen pokok dalam pembelajaran online, yang meliputi konten, sosial emosional, tanya jawab, refleksi dan evaluasi. Penelitian ini bertujuan untuk mendeskripsikan efektifitas penerapan multimodal model melalui e-learning pada pembelajaran geometri bidang. Jenis penelitian ini adalah deskriptif. Subjek penelitian adalah mahasiswa semester 1 program studi pendidikan matematika sebanyak 63 mahasiswa. Pengumpulan data menggunakan teknik dokumentasi, observasi dan tes. Hasil penelitian menunjukkan bahwa penerapan multimodal model efektif dalam pembelajaran geometri bidang. Komponen multimodal model meliputi konten, tanya jawab, sosial emosional, evaluasi dan refleksi dapat terlaksana dengan baik melalui e-learning. Penerapan multimodal model melalui e-learning membutuhkan aplikasi pendukung agar dapat optimal dalam pelaksanaannya, terutama pada komponen sosial emosional dan tanya jawab. selain itu, penerapan multimodal model dapat menumbuhkan kreatifitas dosen dalam menciptakan media yang mendukung pembelajaran online, seperti video berbasis powerpoint dan audio.
\end{abstract}

Kata Kunci: E-learning; geometri bidang; multimodal model; pandemi covid 19.

\begin{abstract}
During the Covid 19 pandemic, learning was carried out online by utilizing e-learning. The multimodal model is a key component in online learning, which includes content, social emotional, question and answer, reflection and evaluation. This study aims to describe the effectiveness of the application of the multimodal model through e-learning in field geometry learning. This type of research is descriptive. The research subjects were the first semester students of the mathematics education study program, totaling 63 students. Collecting data using documentation techniques, observation and tests. The results showed that the application of the multimodal model was effective in learning field geometry. The multimodal components of the model including content, question and answer, social emotional, evaluation and reflection can be carried out well through e-learning. The application of the multimodal model through elearning requires supporting applications so that it can be optimal in its implementation, especially in the social emotional component and question and answer. In addition, the application of the multimodal model can foster the creativity of lecturers in creating media that supports online learning, such as powerpoint-based videos and audio.
\end{abstract}

Keywords: Covid-19 pandemic; e-learning; field geometry; multimodal.

This is an open access article under the Creative Commons Attribution 4.0 International License 
DOI: https://doi.org/10.24127/ajpm.v10i1.3414

\section{PENDAHULUAN}

Semenjak diumumkannya wabah covid yang melanda hampir di seluruh negara di dunia, semua aktifitas lumpuh. Semua bidang membatasi adanya kegiatan yang dilakukan dengan interaksi (tatap muka) secara langsung. Hal ini dimaksudkan untuk mengurangi penyebaran virus covid 19.

Bidang pendidikan merupakan bidang yang paling merasakan dampak pandemi covid 19 (Loviana \& Baskara, 2020; Warmi et al., 2020). Adanya pandemi covid 19 menuntut pelaku pendidikan untuk memutar arah sistem pembelajaran dari konvensional (faceto-face) menjadi pembelajaran secara online. Sampai dengan akhir tahun 2020 ini pelaksanaan pembelajaran dilaksanakan sepenuhnya secara online (fully online) (Trenholm \& Peschke, 2020). Hal ini juga terjadi dalam pembelajaran matematika.

Pembelajaran secara daring dapat menghubungkan mahasiswa dengan sumber belajarnya (database, pakar/instruktur, perpustakaan) yang secara fisik terpisah atau bahkan berjauhan sehingga dapat saling berkomunikasi, berinteraksi atau berkolaborasi secara langsung (synchronous) maupun secara tidak langsung (asynchronous) (Sadikin \& Hamidah, 2020). Melalui pembelajaran secara online proses belajar dapat berjalan kapan pun dan dimana pun.

Pembelajaran secara online memungkinkan tersedianya berbagai fasilitas media pembelajaran yang variatif seperti media video pembelajaran yang terhubung ke youtube, media video conference, media jurnal ilmiah atau topik yang tersistem secara digital. Pembelajaran secara online memungkinkan mahasiswa mendapatkan pengalaman belajar yang dapat meningkatkan motivasi dan antusiasme siswa dalam belajar.

Salah satu alternatif pembelajaran online adalah dengan memanfaatkan $e$ learning. Pembelajaran e-learning adalah konsep pembelajaran yang dalam prosesnya memanfaatkan perkembangan kemajuan teknologi informasi dan komunikasi (Fitriani \& Nurjannah, 2019). Pemanfaatan e-learning memudahkan mahasiswa untuk belajar dan mengakses informasi terkait materi tanpa batas ruang dan waktu sehingga proses pembelajaran akan lebih mudah dan praktis.

E-learning sebagai salah satu metode pembelajaran online yang sangat sesuai untuk pendidikan tinggi (Moreno-Guerrero, Aznar-Díaz, Cáceres-Reche, \& Alonso-García, 2020; Trenholm \& Peschke, 2020). Pembelajaran ini merupakan konsep pembelajaran orang dewasa. Oleh sebab itu, penggunaan e-learning ini sangat sesuai untuk mahasiswa.

Pembelajaran secara online dengan memanfaatkan e-learning harus mempertimbangkan hubungan komplek antara teknologi, pedagogi dan pembelajaran untuk membentuk pengalaman belajar-mengajar yang sukses (Khoo, Forret, \& Cowie, 2010). Selain penguasaan teknologi, komponen pedagogik juga harus dikuasai dengan baik. Teknik untuk mentransformasi pembelajaran dari offline ke online harus tepat agar tujuan pembelajaran dapat tercapai.

Penggunaan e-learning dapat dipadukan dengan media online. Berbagai media pembelajaran online yang efektif dalam pembelajaran, diantaranya media whatsapp (Wargadinata, Maimunah, Dewi, \& Rofiq, 2020), media video conference seperti google classroom, google meet (Basilaia \& Kvavadze, 2020; Hakim \& 
Mulyapradana, 2020; Nurani, Uswatun, \& Maula, 2020). Media tersebut membantu mendukung pembelajaran online.

Pembelajaran daring di universitas PGRI Madiun dilaksanakan melalui $e$ learning universitas dalam bentuk platform moodle. Platform moodle berisi semua konten yang akan dibahas selama satu semester. Platform moodle terdiri dari teori, latihan dan forum (Moreno-Guerrero et al., 2020). Dalam e-learning teori dibentuk dari aspek teoritis mata pelajaran, disajikan dalam format pdf atau video. Latihan berisi kegiatan untuk menunjukkan akuisisi konten dari teori. Latihan terdiri dari kegiatan untuk menunjukkan perolehan konten teoritis, yang meliputi pengenalan, pengembangan, konsolidasi, evaluasi dan penguatan. Latihan dalam e-learning disajikan dalam berbagai tipe, antara lain: jawaban pendek, jawaban panjang, soal Benar Salah, pilihan ganda dan menghubungkan soal dan jawaban.

Penggunaan e-learning telah banyak diterapkan dan dinyatakan efektif dalam pembelajaran matematika (Kusumaningrum \& Wijayanto, 2020; Moreno-Guerrero et al., 2020; Mustakim, 2020). Metode e-learning berpengaruh positif terhadap peningkatan motivasi, kemandirian, partisipasi, konsep matematika, hasil belajar, dan prestasi belajar matematika (Fitriani \& Nurjannah, 2019; Moreno-Guerrero et al., 2020). Penggunaan e-learning menjadikan mahasiswa bertanggung jawab terhadap pem-belajarannya sendiri sehingga dapat meningkatkan pemahaman konsep dan hasil belajar yang lebih baik.

Penerapan e-learning dalam pembelajaran telah terbukti efektif. $E$ learning pada dasarnya adalah sistem pembelajaran yang dilaksanakan tanpa tatap muka secara langsung. Sebelum adanya pandemi, e-learning digunakan secara blended, yaitu kombinasi antara pembelajaran daring dengan tatap muka. Selama pandemi pembelajaran dilaksanakan secara fully online (Trenholm \& Peschke, 2020), menggunakan e-learning tanpa adanya tatap muka secara langsung. Sejauh ini belum ada penelitian yang menjelaskan tentang pelaksanaan pembelajaran secara fully online.

Pembelajaran secara daring harus dirancang dengan tepat agar dapat berjalan sebagaimana pembelajaran secara tatap muka. Salah satu pendekatan yang dapat diterapkan dalam pembelajaran secara online adalah multimodal model. The multimodal suggests that blending the objectives, activities, and approaches within multiple modalities might be most effective for, and appeal to, a wide range of students (Picciano, 2017). Multimodal model menyarankan pencampuran tujuan, kegiatan, dan pendekatan dalam berbagai modalitas yang memungkinkan pembelajaran paling efektif, dan menarik bagi mahasiswa. Model ini terdiri dari tujuh komponen pedagogik dasar dan pendekatan untuk mencapainya. Tujuh komponen tersebut adalah konten, sosial dan emosional, dialektika atau tanya jawab, refleksi, pembelajaran kolaboratif, belajar mandiri dan evaluasi (Picciano, 2009; Picciano, 2017). Multimodal model sangat fleksibel, keenam komponen dalam multimodal model dapat ditambahkan komponen yang lain tergantung pendekatan yang digunakan. Pembelajaran secara daring harus menggunakan strategi yang lebih bervariasi agar dapat menunjang percepatan adaptasi mahasiswa (Annur \& Hermansyah, 2020). 
DOI: https://doi.org/10.24127/ajpm.v10i1.3414

Multimodal model sangat sesuai diterapkan dalam pembelajaran secara daring melalui e-learning. Penelitian ini bertujuan untuk mendeskripsikan efektifitas pembelajaran daring melalui e-learning dengan menggunakan multimodal model pada mata kuliah Geometri Bidang. Multimodal model yang diterapkan dalam penelitian ini meliputi komponen konten, sosial emosional, dialektika (tanya jawab), refleksi dan evaluasi. Geometri bidang merupakan geometri yang akan menjadi dasar geometri lanjutan. Oleh sebab itu, penguasaan terhadap materi geometri bidang harus baik.

Hasil penelitian ini memberikan inspirasi bagi dosen maupun praktisi pembelajaran berupa gambaran yang jelas tentang penyelenggaraan pembelajaran geometri secara online dengan menerapkan multimodal model berbantuan e-learning.

\section{METODE PENELITIAN}

Penelitian ini dilaksanakan di Universitas PGRI Madiun pada semester gasal tahun akademik 2020/2021. Subjek penelitian adalah mahasiswa semester 1 Program Studi Pendidikan Matematika sebanyak 63 mahasiswa. Jenis penelitian ini adalah deskriptif dengan pendekatan kualitatif. Penelitian ini dilaksanakan pada saat kondisi darurat covid 19. Oleh sebab itu, pembelajaran sepenuhnya dilaksanakan secara daring menggunakan e-learning Universitas PGRI Madiun dalam bentuk platform moodle.

Prosedur penelitian ini meliputi persiapan, pelaksanaan, analisis data dan penulisan laporan. Persiapan meliputi penyiapan materi, media dan bahan ajar untuk tiap pertemuan. Pelaksanaan mengikuti langkah-langkah multimodal model, yaitu penyajian materi dalam e-learning, diskusi (sinkronus maupun asinkronus), evaluasi dalam e-learning. Setiap pertemuan dilakukan pengumpulan data aktifitas siswa dalam diskusi (sinkronus maupun asinkronus). Analisis data dilakukan setelah pertemuan keenam. Langkah terakhir adalah penulisan laporan.

Pengumpulan data dalam penelitian inimenggunakan teknik dokumentasi dan tes. Dokumentasi digunakan untuk mendapatkan data keaktifan mahasiswa dalam diskusi di elearning. Tes digunakan untuk mendapatkan data hasil belajar mahasiswa. Analisis data yang digunakan dalam penelitian ini yaitu melalui reduksi data, penyajian data dan penarikan kesimpulan (Miles \& Huberman, 2007).

Indikator efektivitas yang digunakan dalam penelitian ini adalah persentase ketuntasan hasil belajar mahasiswa minimal $75 \%$ baik secara individu maupun klasikal (Masfingatin, Murtafiah, \& Krisdiana, 2017). Keaktifan mahasiswa berdasarkan banyaknya partisipasi mahasiswa dan dosen dalam diskusi baik sinkronus maupun asinkronus.

\section{HASIL DAN PEMBAHASAN}

Pada masa Pandemi Covid 19 seluruh kegiatan pembelajaran dilaksanakan secara online. Pelaksanaan pembelajaran di Program Studi Pendidikan Matematika Universitas PGRI Madiun memanfaatkan e-learning Universitas PGRI Madiun. Oleh karena itu. penelitian ini dilaksanakan selama 6 kali pertemuan secara online. Setiap pertemuan mencakup lima komponen pembelajaran secara daring, yaitu konten (pemberian materi), sosial emosional, diskusi (tanya jawab), evaluasi dan refleksi. 
DOI: https://doi.org/10.24127/ajpm.v10i1.3414

Penyajian materi atau konten dalam e-learning terdiri dari berbagai bentuk, yaitu materi dari e-book yang berupa Portable Document Format (.pdf), Microsoft Office Powerpoint (.ppt) dan video pembelajaran. Pemberian materi ini bertujuan agar mahasiswa mendapatkan berbagai sumber belajar yang relevan, sehingga mahasiswa dapat mengakses dan mempelajari materi secara mandiri. Materi dalam bentuk file powerpoint maupun e-book diunggah dalam google drive, selanjutnya link dari google drive di sematkan di e-learning. Gambar 1. merupakan contoh penyajian materi dalam e-learning dalam bentuk e-book dan powerpoint.

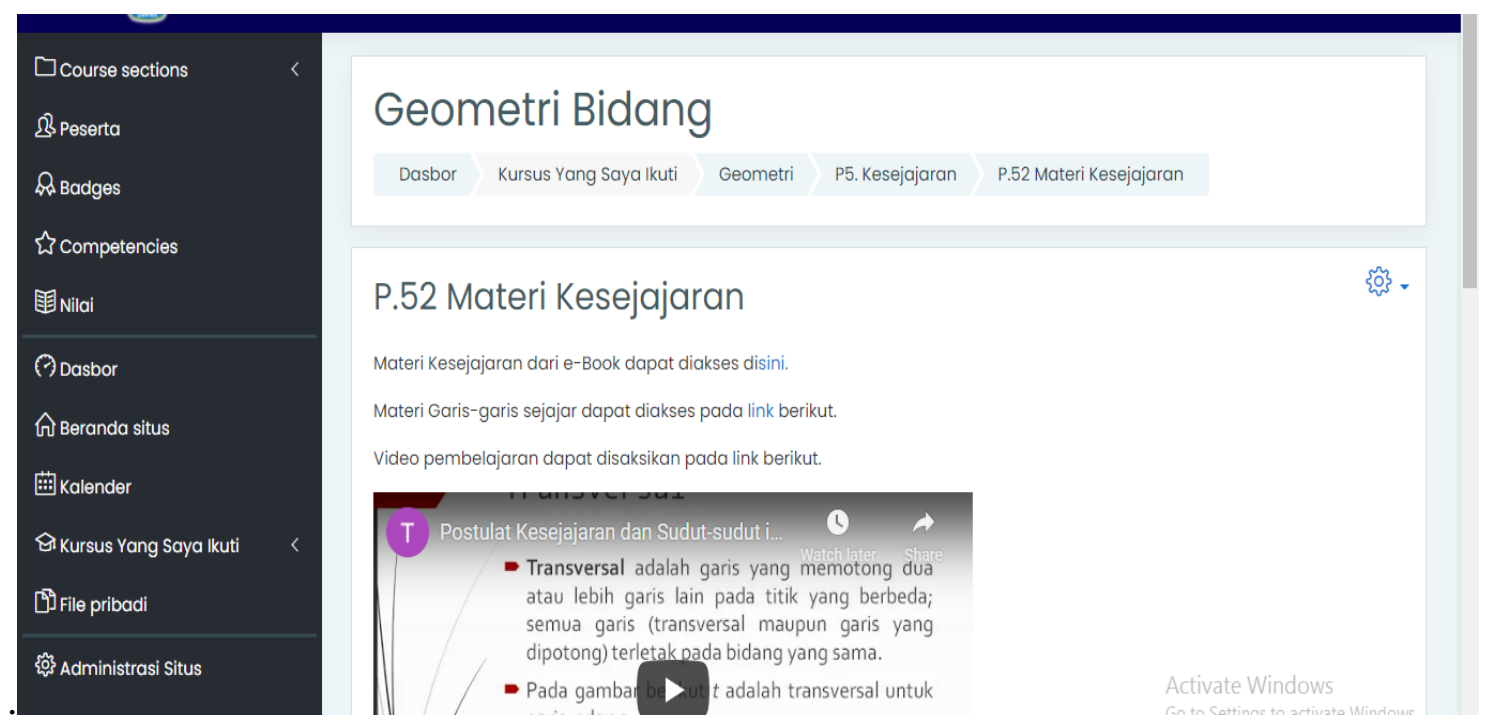

Gambar 1. Sajian konten materi dalam e-learning.

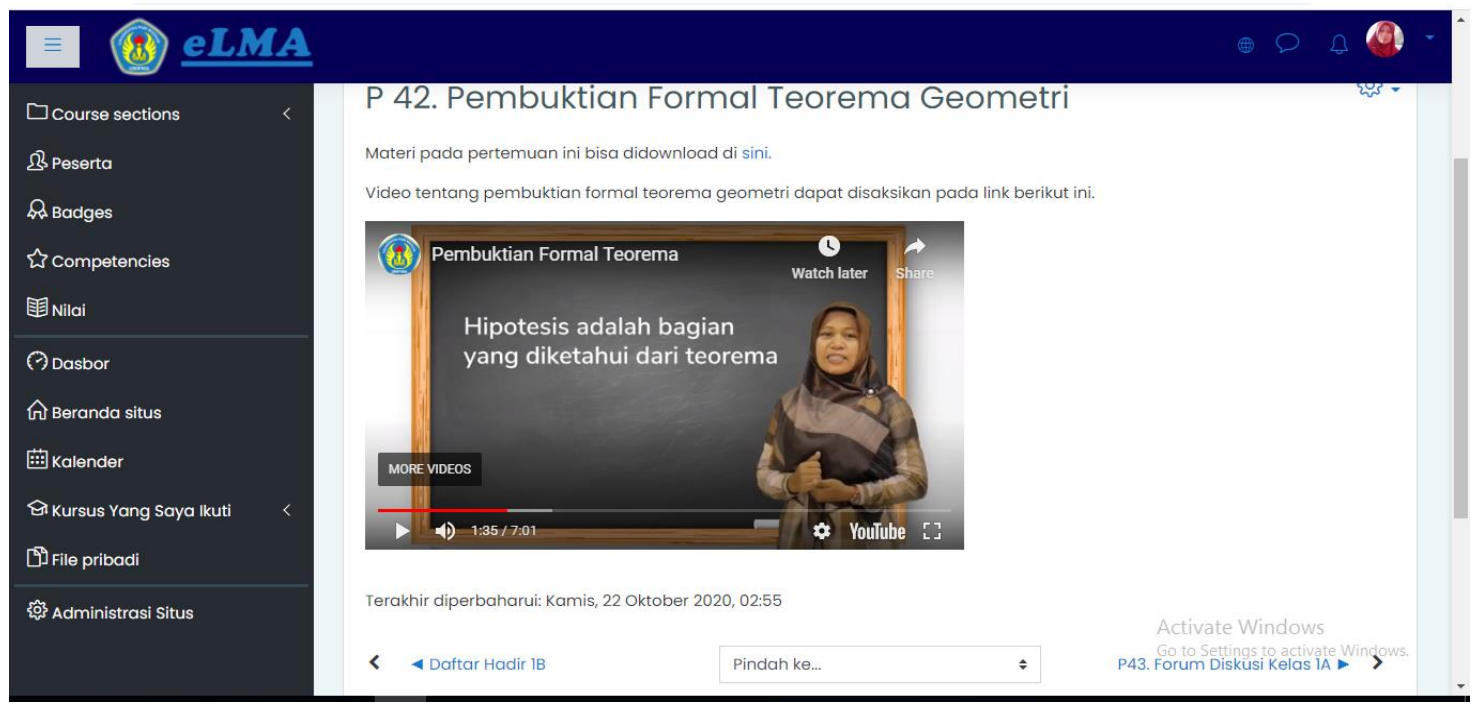

Gambar 2.Sajian materi dalam bentuk video pembelajaran

Selain materi dalam bentuk file, juga disajikan materi dalam bentuk video pembelajaran. Beberapa pertemuan menggunakan video pembelajaran berupa powerpoint dilengkapi audio dari dosen. Hal ini didukung oleh (Sankey, Birch, \& Gardiner, 2010) bahwa powerpoint 
DOI: $\underline{\text { https://doi.org/10.24127/ajpm.v10i1.3414 }}$

yang dilengkapi dengan audio merupakan tipe representasi materi dalam multimodal learning yang paling efektif membawa siswa untuk mengembangkan pemahaman terhadap materi. Satu kali pertemuan disajikan satu atau dua video dengan durasi antara 10 sampai dengan 15 menit. Materi video diunggah di Youtube dan link-nya disematkan di e-learning. Gambar 2 . merupakan contoh sajian materi pembelajaran dalam bentuk video.

Komponen kedua dalam

Multimodal Model menggunakan $e$ learning adalah tanya jawab. Tanya jawab dilaksanakan dalam bentuk diskusi baik secara sinkronus maupun asinkronus. Langkah ini dilaksanakan setelah mahasiswa mempelajari materi dalam e-learning. Diskusi dengan mengambil topik yang berkaitan dengan materi pada masing-masing pertemuan. Diskusi secara sinkronus menggunakan google meet, sedangkan secara asinkronus menggunakan forum diskusi di e-learning. Diskusi secara sinkronus dilaksanakan dalam waktu 1 x 50' setara 1 SKS. Gambar 3 menunjukkan diskusi secara sinkronus menggunakan google meet.

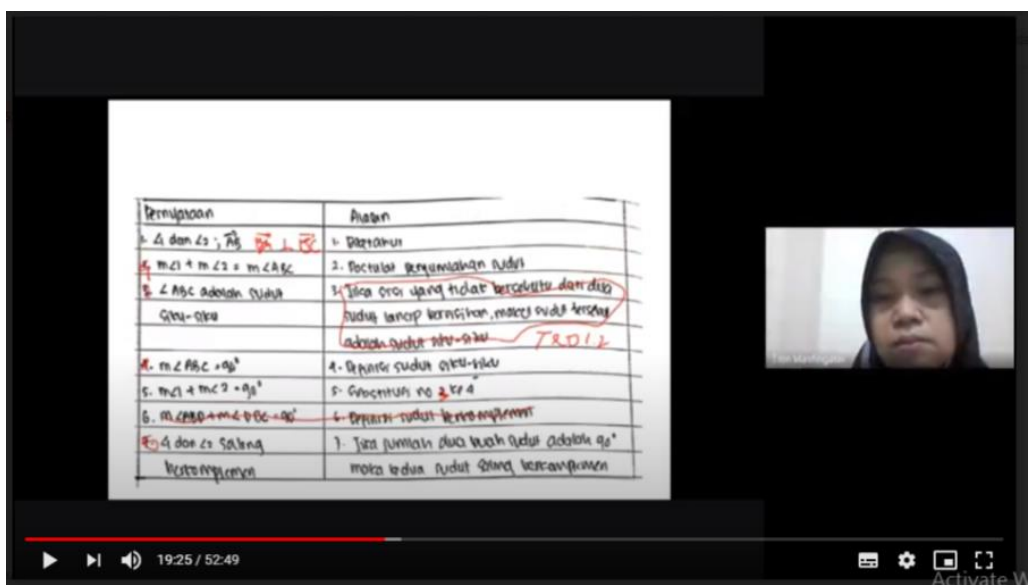

Gambar 3. Diskusi sinkronus via google meet

Gambar 4 menunjukkan salah satu diskusi secara sinkronus melalui google meet. Penggunaan media video conference seperti Google classroom, google meet (Basilaia \& Kvavadze, 2020; Hakim \& Mulyapradana, 2020; Nurani et al., 2020) sangat direkomendasikan dan efektif dalam pembelajaran secara daring. Diskusi secara sinkronus memungkinkan mahasiswa dengan dosen untuk melakukan tatap maya. Diskusi yang bersifat sinkronus membuat mahasiswa merasa senang secara sosial emosional. Ini merupakan komponen multimodal yang kedua (Picciano, 2017).
Selain diskusi virtual secara sinkronus juga dilakukan diskusi secara asinkronus. Gambar 4 menunjukkan diskusi secara asinkronus, yaitu dengan memanfaatkan forum diskusi di $e$ learning. Diskusi diawali dengan penyajian topik dari dosen atau mahasiswa, kemudian mahasiswa menanggapi topik tersebut. Setiap mahasiswa berkesempatan memberikan pendapatnya dengan tidak ada pembatasan waktu diskusi. Pendapat mahasiswa yang kurang tepat dapat ditanggapi oleh dosen atau mahasiswa lain. 


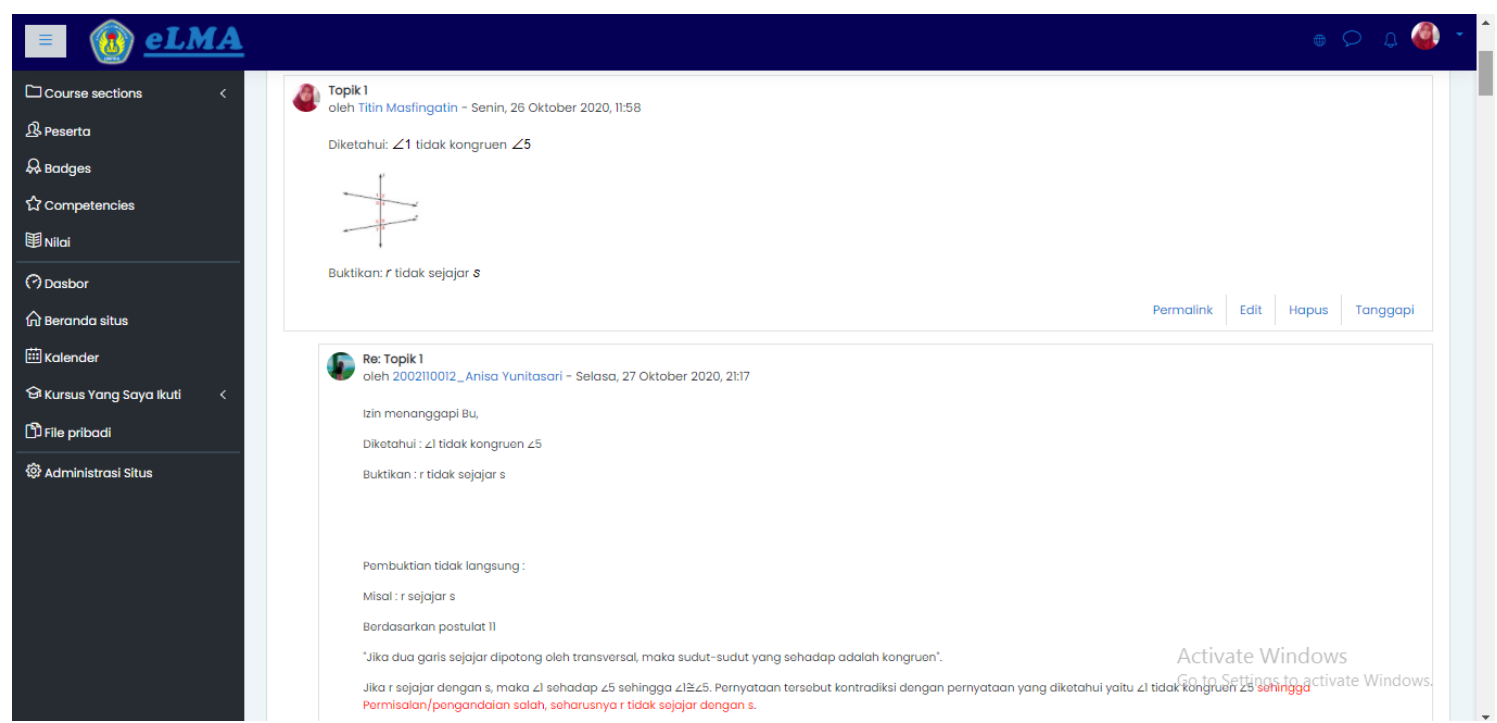

Gambar 4. Diskusi asinkronus dalam forum diskusi di e-learning

Setelah proses pembelajaran selesai tiap akhir pertemuan diberikan evaluasi seperti pada Gambar 5. Evaluasi disampaikan dalam e-learning dengan berbagai variasi, diantaranya pilihan ganda, soal tipe Benar-Salah, soal jawab singkat dan Soal Essay. Evaluasi ini bertujuan untuk mengetahui penguasaan mahasiswa terhadap materi pembelajaran.

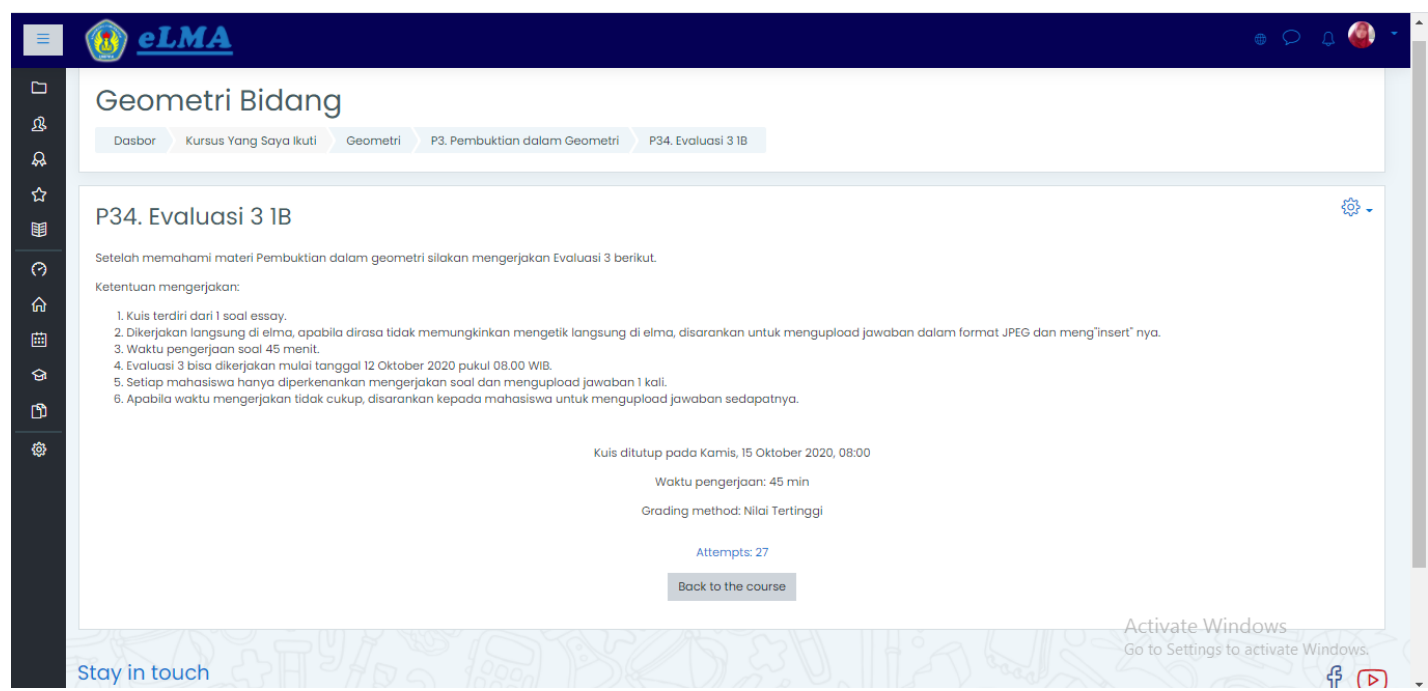

Gambar 5. Contoh evaluasi dalam e-learning

Setiap mahasiswa mengerjakan soal evaluasi dan mengupload jawaban melalui e-learning. Dalam pembelajaran geometri bidang, evaluasi dilaksanakan langsung menjawab di e-learning atau upload jawaban. Sebagai tindak lanjut atas evaluasi sekaligus sebagai refleksi bagi mahasiswa dosen mengoreksi jawaban dan memberikan skor. Selain itu, dosen juga memberikan pembahasan atas soal yang diberikan untuk menambah pemahaman mahasiswa. Pembahasan biasanya diberikan setelah semua pekerjaan mahasiswa dikoreksi. Salah satu bentuk pembahasan dari soal evaluasi yang diberikan dapat dilihat pada Gambar 6. 


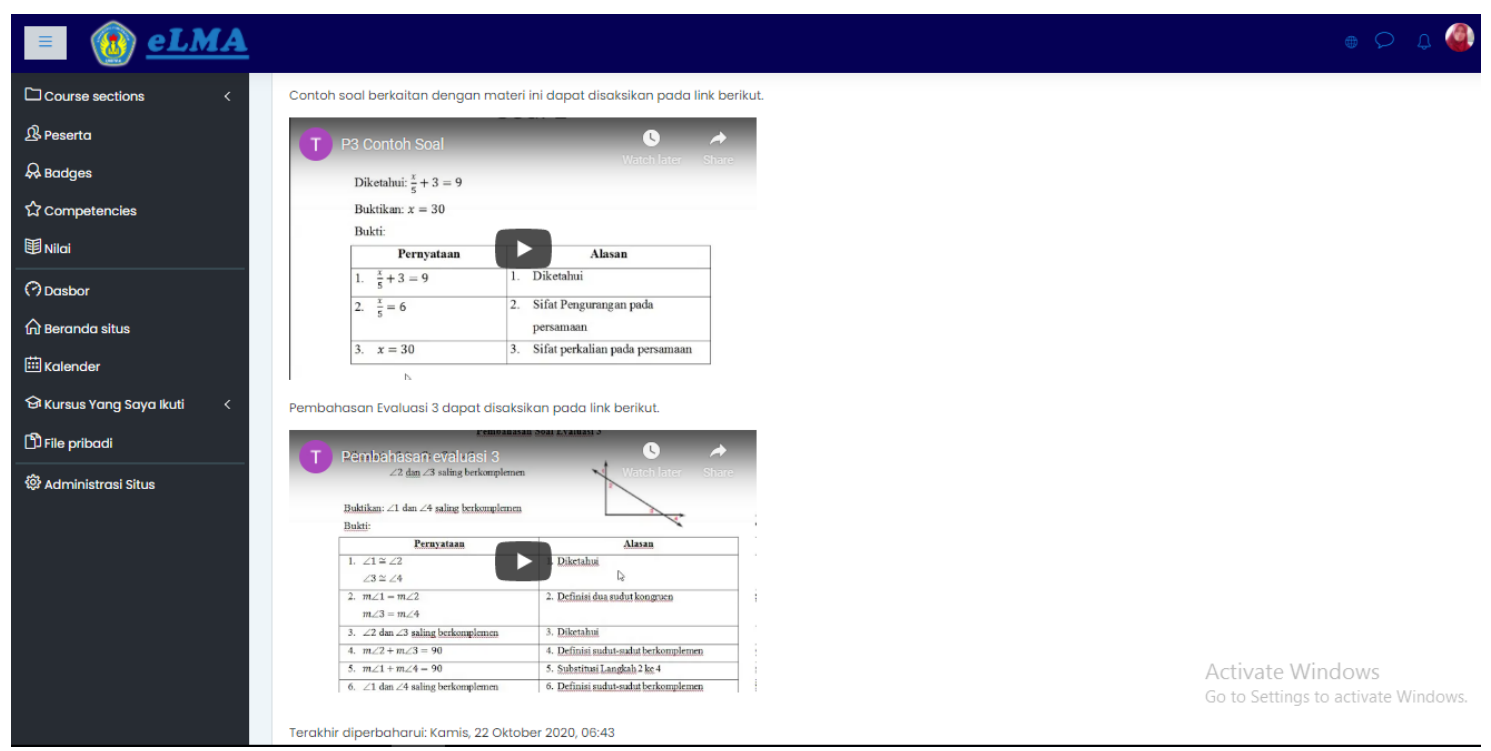

Gambar 6. Refleksi dalam e-learning

Penerapan pembelajaran online dengan memanfaatkan e-learning ini diawali dengan presentasi materi dari dosen dengan memanfaatkan materi secara online yang di upload di elearning. Materi yang disajikan berupa video pembelajaran atau powerpoint dengan audio. Video yang disajikan dalam durasi 10 sampai dengan 15 menit (Picciano, 2017). Berdasarkan materi dari video dan beberapa materi lain yang diupload di e-learning, seperti powerpoint dan e-book, mahasiswa diminta menanggapi beberapa topik yang telah disajikan dalam materi video. Selanjutnya dilakukan diskusi terkait topik yang disajikan. Diskusi dilakukan baik secara sinkronus maupun asinkronus. Diskusi secara sinkronus dilakukan melalui google meet. Dalam pembelajaran online dengan e-learning dikolaborasikan dengan google meet sebagai aplikasi pendukung. Menurut (Basilaia \& Kvavadze, 2020) penggunaan google meet merupakan media paling cepat untuk transisi pembelajaran system off-line ke system on-line. Selain itu, google meet merupakan aplikasi yang tidak berbayar sehingga menjadi pertimbangan efisiensi biaya baik bagi dosen maupun mahasiswa. Diskusi asinkronus melalui forum diskusi di e-learning.

Dosen memandu jalannya diskusi. Melalui diskusi ini mahasiswa diarahkan agar dapat menganalisis permasalahan yang disajikan dalam $e$ learning. Selanjutnya terjadi saling sharing ide-ide sehingga terjadi konstruksi pengetahuan. Fase pembelajaran berikutnya adalah evaluasi. Evaluasi dilakukan melalui $e$ learning. Berbagai jenis evaluasi yang dilakukan untuk mengetahui sejauh mana kemampuan mahasiswa dalam menyerap materi yang dipelajari.Hal ini sejalan dengan (Harasim, 2012; Picciano, 2017) bahwa dalam pembelajaran secara online konstruksi pengetahuan melalui tiga fase, yaitu penghasil ide, pengorganisasian ide dan konvergensi intelektual.

Keaktifan mahasiswa dalam pembelajaran diamati berdasarkan partisipasi mahasiswa dalam diskusi. Hasil pengamatan terhadap partisipasi mahasiswa dalam diskusi baik secara sinkronus maupun asinkronus menunjukkan peningkatan partisipasi secara keseluruhan selama periode 
perkuliahan, yaitu mulai dari pertemuan pertama sampai dengan pertemuan keenam. Semua mahasiswa berpartisipasi dalam diskusi, dengan total 437 kontribusi mahasiswa. Dosen memberikan 52 kontribusi online. Partisipasi dosen secara umum dalam mata kuliah pada awalnya cukup tinggi namun secara bertahap menurun seiring dengan semakin aktifnya peran dan bentuk interaksi mahasiswa (Khoo \& Cowie, 2010; Khoo et al., 2010). Pembelajaran yang dilaksanakan dalam e-learning menfasilitasi mahasiswa untuk berinteraksi sosial dalam diskusi baik secara sinkronus maupun asinkronus. Hal ini sejalan dengan (Khoo et al., 2010) bahwa online learning is a social and interactive process as embodied by participation in a learning community. Proses pembelajaran online bersifat sosial dan interaktifyang diwujudkan dengan partisipasi dalam komunitas belajar.

Hasil belajar mahasiswa pada aspek kognitif diperoleh dari data hasil ujian tengah semester gasal 2020-2021. Hasil analisis menunjukkan bahwa sebesar 80,65\% mahasiswa tuntas belajar. Hal ini menunjukkan pembelajaran geometri bidang efektif (Masfingatin et al., 2017).

Penerapan multimodal model efektif dalam pembelajaran geometri bidang menggunakan e-learning, baik dari sisi ketuntasan hasil belajar maupun keaktifan mahasiswa. Adanya konten dalam multimodal yang disajikan dalam bentuk video, video berbasis powerpoint dapat membuat mahasiswa secara sosial emosional mendapat dukungan dari dosen seperti halnya pembelajaran tatap muka. Hal ini sangat dibutuhkan mahasiswa selama belajar secara fully online. Selain itu pembahasan tugas-tugas menggunakan video dengan audio berbasis teks dapat menjelaskan secara detail pada mahasiswa (Lowenthal, 2020).

Hasil penelitian ini sejalan dengan (Al fadda \& Liu, 2020; MorenoGuerrero et al., 2020; Mustakim, 2020) bahwa penerapan multimodal dalam pembelajaran melalui e-learning memberikan dampak positif bagi siswa. Penggunaan media online dalam pembelajaran daring memungkinkan mahasiswa untuk memiliki semangat yang tinggi untuk belajar dan mengerjakan tugas dengan beragam metode. E-learning sangat sesuai untuk mahasiswa (Moreno-Guerrero et al., 2020). Penggunaan e-learning berpengaruh positif terhadap motivasi, partisipasi dan prestasi mahasiswa. Penggunaan e-learning dalam pembelajaran secara online selama pandemic covid 19 merupakan pilihan yang tepat dan digunakan oleh hampir seluruh perguruan tinggi (Al fadda \& Liu, 2020; Irfan, Kusumaningrum, Yulia, \& Widodo, 2020; Wiratomo \& Mulyatna, 2020). Hal ini juga didukung penelitian (Muthy \& Pujiastuti, 2020) bahwa pemilihan e-learning sebagai media pembelajaran sesuai dengan criteria ACTION (Access, Cost, Technology, Interactivity, Organization, Novelty) serta melatihkan keterampilan abad 21 baik bagi mahasiswa maupun dosen.

Penerapan multimodal model dalam pembelajaran geometri memberikan implikasi pada kreatifitas dosen dalam menciptakan media yang mendukung pembelajaran online. Hasil ini sejalan dengan (Al fadda \& Liu, 2020). Oleh sebab itu, dosen harus paham teknologi. Agar dosen dapat menerapkan multimodal model minimal harus menguasai aplikasi pendukung, antara lain aplikasi edit video, powerpoint dengan audio, video conference dan edit teks. 


\section{KESIMPULAN DAN SARAN}

Multimodal model melalui penggunaan e-learning efektif dalam pembelajaran geometri bidang, baik dari sisi kognitif maupun afektif. Persentase ketuntasan belajar mahasiswa sebesar $80,65 \%$ dan keaktifan mahasiswa dalam diskusi secara sinkronus maupun asinkronus sebesar $75,37 \%$ melalui penerapan multimodal model menggunakan e-learning. Selain itu, penerapan multimodal model dapat menambah kreatifitas dosen dalam menyampaikan materi pembelajaran secara fully online.

Bagi penelitian selanjutnya agar mengkaji lebih mendalam tentang penerapan multimodal model pada pembelajaran secara daring menggunakan e-learning pada mata kuliah lainnya.

\section{DAFTAR PUSTAKA}

Al fadda, H., \& Liu, C. (2020). The Promises and Challenges of Multimodal Online Learning in Saudi Arabia. Revista Argentina de Clínica Psicológica, XXIX(4), 952-962.

https://doi.org/10.24205/03276716. 2020.1506

Annur, M. F., \& Hermansyah, H. (2020). Analisis Kesulitan Mahasiswa Pendidikan Matematika dalam Pembelajaran Daring Pada Masa Pandemi Covid19. Paedagoria: Jurnal Kajian, Penelitian Dan Pengembangan Kependidikan, 11(2), 195-201.

Basilaia, G., \& Kvavadze, D. (2020). Transition to Online Education in Schools during a SARS-CoV-2 Coronavirus (COVID-19)

Pandemic in Georgia. Pedagogical Research, $5(4)$. https://doi.org/10.29333/pr/7937
Fitriani, \& Nurjannah. (2019). Peranan E-Learning dalam Pembelajaran Matematika Di Sekolah Menengah Pertama (SMP). Journal on Pedagogical Mathematics, 1(2), 102-110. Retrieved from https://ojs.unsulbar.ac.id/index.php /pedamath/article/view/371

Hakim, M., \& Mulyapradana, A. (2020). Pengaruh Penggunaan Media Daring dan Motivasi Belajar Terhadap Kepuasan Mahasiswa Pada Saat Pandemik Covid-19. Widya Cipta: Jurnal Sekretari Dan Manajemen, 4(2), 154-160. https://doi.org/10.31294/widyacipt a.v4i2.8853

Harasim, L. (2012). Learning Theory and Online Technologies. New York: Routledge / Taylor \&Francis.

Irfan, M., Kusumaningrum, B., Yulia, Y., \& Widodo, S. A. (2020). Challenges During the Pandemic: Use of E-Learning in Mathematics Learning in Higher Education. Infinity Journal, 9(2), 147. https://doi.org/10.22460/infinity.v9 i2.p147-158

Khoo, E., \& Cowie, B. (2010). A Framework for Developing and Implementing an Online Learning Community. Journal of Open, Flexible and Distance Learning, 15(1), 47-59. https://doi.org/10.1021/om00046a0 44

Khoo, E., Forret, M., \& Cowie, B. (2010). Lecturer-student views on successful online learning environments. Waikato Journal of Education, 15(3), 17-33. https://doi.org/10.15663/wje.v15i3. 79

Kusumaningrum, B., \& Wijayanto, Z. (2020). Apakah Pembelajaran Matematika Secara Daring 
DOI: https://doi.org/10.24127/ajpm.v10i1.3414

Efektif? ( Studi Kasus pada Pembelajaran Selama Masa Pandemi. Kreano , Jurnal Matematika Kreatif-Inovatif, 11(2), 139-146.

Loviana, S., \& Baskara, W. N. (2020). Dampak Pandemi Covid-19 Pada Kesiapan Pembelajaran Tadris Matematika IAIN Metro Lampung. Epsilon, 1(2), 61-70. https://doi.org/10.1017/CBO97811 07415324.004

Lowenthal, P. R. (2020). Video feedback: is it worth the effort? A response to Borup et al. Educational Technology Research and Development, (January). https://doi.org/10.1007/s11423020-09872-4

Masfingatin, T., Murtafiah, W., \& Krisdiana, I. (2017). Pembelajaran berbasis riset untuk mengembangkan kompetensi profesional mahasiswa pada mata kuliah geometri. In Prosiding Seminar Hasil Penelitian dan Pengabdian Kepada Masyarakat UNIPMA 2017 (pp. 139-145).

Miles, M. B., \& Huberman, M. (2007). Analisis Data Kualitatif. Jakarta: Penerbit Universitas Indonesia.

Moreno-Guerrero, A. J., Aznar-Díaz, I., Cáceres-Reche, P., \& AlonsoGarcía, S. (2020). E-learning in the teaching of mathematics: An educational experience in adult high school. Mathematics, 8(5). https://doi.org/10.3390/MATH805 0840

Mustakim. (2020). Efektivitas Pembelajaran Daring Menggunakan Media Online Selama Pandemi Covid-19 Pada Mata Pelajaran Matematika. Al Asma: Journal of Islamic Education, 2(1), 1-12.
Muthy, A. N., \& Pujiastuti, H. (2020). Analisis media pembelajaran elearning melalui pemanfaatan teknologi dalam pembelajaran matematika di rumah sebagai dampak 2019-nCoV. Jurnal Math Educator Nusantara: Wahana Publikasi Karya Tulis Ilmiah Di Bidang Pendidikan Matematika, 6(1), 94-103. https://doi.org/10.29407/jmen.v6i1. 14356

Nurani, N. I., Uswatun, D. A., \& Maula, L. H. (2020). Analisis Proses Pembelajaran Matematika Berbasis Daring Menggunakan Aplikasi Google Classroom Pada Masa Pandemi Covid-19. Jurnal PGSD, 6(1), 50-56.

Picciano, A. G. (2009). Blending with purpose: The multimodal model. Journal of Asynchronous Learning Network, 13(1), 7-18. https://doi.org/10.24059/olj.v13i1. 1673

Picciano, A. G. (2017). Theories and frameworks for online education: Seeking an integrated model. Online Learning Journal, 21(3), 166-190. https://doi.org/10.24059/olj.v21i3. 1225

Sadikin, A., \& Hamidah, A. (2020). Pembelajaran Daring di Tengah Wabah Covid-19. Biodik, 6(2), 109-119.

https://doi.org/10.22437/bio.v6i2.9 759

Sankey, M., Birch, D., \& Gardiner, M. (2010). Engaging students through multimodal learning environments : The journey continues. In C.H. Steel, M.J. Keppell, P. Gerbic \& S. Housego (Eds.), Curriculum, technology \& transformation for an unknown future. Proceedings ascilite Sydney 
DOI: https://doi.org/10.24127/ajpm.v10i1.3414

2010 (pp. 852-863). Retrieved from

http://ascilite.org.au/conferences/sy dney10/procs/Sankey-full.pdf\%0A

Trenholm, S., \& Peschke, J. (2020). Teaching undergraduate mathematics fully online: a review from the perspective of communities of practice. International Journal of Educational Technology in Higher Education, 17(1). https://doi.org/10.1186/s41239020-00215-0

Wargadinata, W., Maimunah, I., Dewi, E., \& Rofiq, Z. (2020). Student's Responses on Learning in the Early COVID-19 Pandemic. Tadris: Jurnal Keguruan Dan Ilmu Tarbiyah, 5(1), 141-153. https://doi.org/10.24042/tadris.v5i1 .6153
Warmi, A., Adirakasiwi, A. G., Santoso, E., Karawang, U. S., Majalengka, U., Siswa, K. B., \& Daring, P. (2020). Motivasi dan Kemandirian Belajar Siswa Pada Mata Pelajaran Matematika di Masa Pandemi Covid-19 (Studi Pada Siswa Kelas VII SMPN 3 Karawang Tahun Pelajaran 20192020). Jurnal Education and Development, 8(3), 197-202.

Wiratomo, Y., \& Mulyatna, F. (2020). Use of Learning Management Systems in Learning Efforts during a Pandemic. Journal of Mathematical Pedagogy (JoMP), 1(2), 62-71. 